\title{
PROCESS FACTORS AFFECTING DEPOSITION RATE OF TiN COATING ON A MACHINE COMPONENT
}

\author{
VPLIVNI PROCESNI FAKTORJI HITROSTI NANOSA TIN \\ PREVLEKE NA STROJNI ELEMENT
}

\author{
Charnnarong Saikaew \\ Department of Industrial Engineering, Faculty of Engineering, Khon Kaen University, 123 Friendship Highway, Mueang Khon Kaen District, \\ Khon Kaen 40002, Thailand \\ Prejem rokopisa - received: 2018-09-07; sprejem za objavo - accepted for publication: 2018-12-17
}

doi: $10.17222 /$ mit.2018.211

\begin{abstract}
In this work, a titanium nitride (TiN) coating applied with the oblique-angle DC-magnetron sputtering technique was systematically studied using designed experiments. The TiN layer was applied on an upper hook, which is a machine component of a fishing-net weaving machine. The goal was to investigate the influence of sputtering process factors on the deposition rate and to find appropriate operating conditions for statistically significant factors in order to improve the thin-film manufacturing process, raising the quality of the TiN coating. Five process factors including the oblique angle, rotational speed, sputtering DC current, operating pressure and $\mathrm{Ar}$ to $\mathrm{N}_{2}$ flow-rate ratio were simultaneously investigated using the $2^{5-1}$ fractional factorial design method. A normal probability plot of effects, and main and interaction-effect plots of the process factors were constructed in order to identify the significant process factors and the appropriate operating conditions. The main factors including the oblique angle, sputtering DC current, operating pressure, gas-mixing ratio, interactions between the oblique angle and sputtering DC current, and interactions between the oblique angle and gas-mixing ratio were found to be statistically significant process factors. Moreover, the appropriate operating conditions for the significant process factors were obtained with the graphical method.

Keywords: TiN, deposition rate, statistical analysis, ANOVA, coating
\end{abstract}

Avtor opisuje sistematično študijo načrtovanih preizkusov nanosa titan nitridne (TiN) prevleke s postopkom poševnokotnega DC magnetronskega naprševanja. TiN prevleka je bila nanešena na zgornji kavelj, ki je strojni element naprave za navijanje ribiške mreže. Cilj študije je bil raziskati vpliv procesnih parametrov naprševanja na hitrost nanašanja prevleke in ugotoviti primerne pogoje delovanja statistično pomembnih faktorjev za izboljšanje kvalitete procesa izdelave tanke TiN prevleke. Istočasno je bilo raziskovanih pet (5) procesnih faktorjev, in sicer nagibni kot, hitrost vrtenja, DC (enosmerni) električni tok naprševanja, delovni tlak in razmerje med hitrostjo pretoka $\mathrm{Ar}$ in $\mathrm{N}_{2}$. Uporabljena je bila $2^{5-1}$ frakcionirana faktorska metoda. Konstruirani so bili grafični prikazi normalne verjetnosti vplivov ter glavnega in interakcijskega učinka pomembnih procesnih faktorjev in ustreznih pogojev delovanja naprave. Avtor ugotavlja, da so statistično pomembni naslednji procesni faktorji: nagibni kot, hitrost vrtenja, jakost enosmernega električnega toka naprševanja, delovni tlak ter razmerje med hitrostjo pretoka plinov in interakcije med kotom nagiba in DC električnim tokom naprševanja ter kotom nagiba in razmerjem hitrosti pretoka plina. Nadalje je avtor s pomočjo grafične metode dobil ustrezne pogoje delovanja naprave glede na pomembnost procesnih faktorjev.

Ključne besede: TiN, hitrost nanosa prevleke, statistična analiza, ANOVA, prevleka

\section{INTRODUCTION}

Titanium nitride is one of extremely hard ceramic materials, widely used as a coating to harden and protect cutting and sliding surfaces due to its excellent characteristic properties such as friction coefficient, hardness, abrasive wear and corrosion resistance under various working conditions. ${ }^{1}$ It has a cubic structure of the $\mathrm{NaCl}$ type with a high modulus of elasticity of $250-450 \mathrm{GPa}$ and a high Vickers hardness of $18-21 \mathrm{GPa}^{2}{ }^{2}$ However, its surface and material properties are considerably dependent on its production process. The most common methods for applying a TiN coating are physical vapor depositions (PVD) including sputtering, filtered cathodic arc, electron-beam evaporation and chemical vapor deposition (CVD). ${ }^{3}$ Among these, sputtering is the most widely used method due to its well-controlled process

*Corresponding author e-mail:

charn_sa@kku.ac.th and high-quality thin-film coating. TiN is normally produced with reactive sputtering, during which sputtered Ti atoms are reacted with nitrogen ions to form TiN molecules. $^{4}$

Oblique-angle-deposition (OAD) or glancing-angledeposition (GLAD) technique is a modified deposition method, in which the substrate is tilted at different angles with respect to the normal of the deposition direction and rotated at an appropriate speed. ${ }^{5}$ Typically, properties and structures of TiN coatings for various applications using this technique depend on coating conditions including oblique angle, Ar pressure, $\mathrm{Ar}$ to $\mathrm{N}_{2}$ flow-rate ratio. ${ }^{6-9}$ The main advantage of this technique is the ability to control the diameter, shape and density of nanostructures by varying the deposition conditions consisting of oblique angle, rotation speed, operating pressure, gas-mixing ratio and sputtering power. The technique is used for a TiN hard coating to produce a high-density nanocolumnar structure that can have an 
extreme hardness, low friction coefficient and very high wear resistance. ${ }^{10}$

Fishing-net companies in Thailand and outside Thailand (owned by Thai people) have confronted the problem of high-cost spare parts of fishing-net weaving machines. In this study, a TiN layer was applied on an upper hook, which is a component of a fishing-net weaving machine as illustrated in Figure 1. The TiN coating applied using the OAD technique with DC magnetron sputtering was systematically studied through designed experiments in order to improve the manufacturing-process quality of the TiN coating on the machine component. Five process factors including oblique angle, rotational speed, sputtering DC current, pressure, and Ar to $\mathrm{N}_{2}$ flow-rate ratio were simultaneously investigated using the fractional factorial design method. The deposition rate was a response used to achieve the effects of the process factors.

\section{MATERIALS AND EXPERIMENTAL PART}

A cast stainless-steel upper hook was made with lost-wax casting and machined with turning and milling operations. The chemical composition of the workpiece material was $62.28 \% \mathrm{Fe}, 6.91 \% \mathrm{Ni}, 21.99 \% \mathrm{Cr}, 3.12 \%$ $\mathrm{Cu}, 1.94 \% \mathrm{Mn}, 2.2 \% \mathrm{Si}$, and $1.56 \% \mathrm{Al}$. A vibratory finishing machine with mixed ball-burnishing media in different sizes ranging from $5 \mathrm{~mm}$ to $8 \mathrm{~mm}$ was used for surface finishing.

In this study, an eight-step method of planning and conducting the experiment was used as described below:

Setting the objectives: The main objectives of this study were to investigate the effects of the sputteringprocess factors on the deposition rate of the TiN coating on the upper hook and to obtain appropriate operating conditions of the statistically significant process factor(s) of the TiN coating. A high deposition rate was preferred to increase the thin-film manufacturing throughput.

Identifying the important process factors: Considering the TiN oblique-angle sputtering process, we identi-

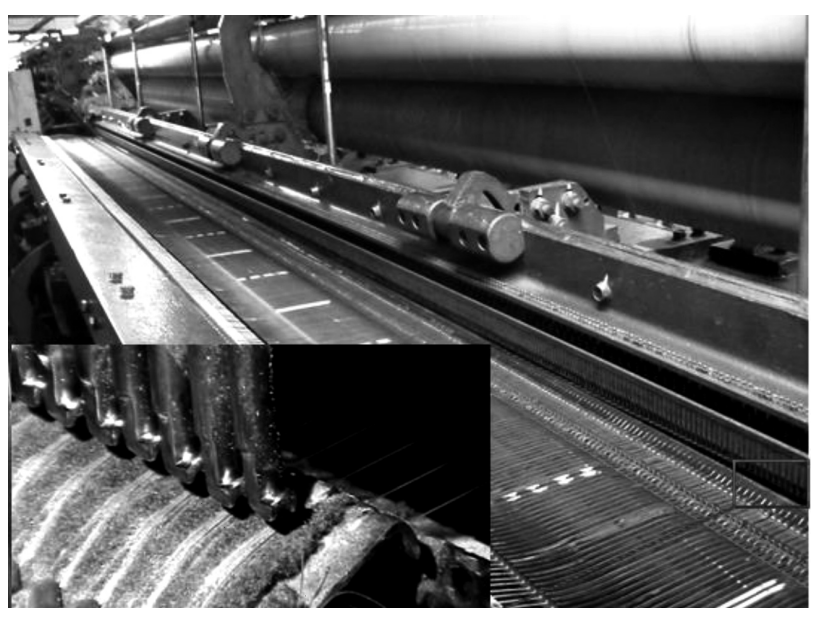

Figure 1: Fishing-net weaving machine and the upper hooks fied five main process factors that control the coating behavior including oblique angle, rotational speed, sputtering DC current, pressure, and $\mathrm{Ar}$ to $\mathrm{N}_{2}$ flow-rate ratio.

Determining the upper and lower limits of the process factors: For the current sputtering system, the ranges of the oblique angle, rotation speed, sputtering DC current, pressure, and Ar to $\mathrm{N}_{2}$ flow-rate ratio were $70^{\circ}$ and $80^{\circ}, 32 \mathrm{~min}^{-1}$ and $64 \mathrm{~min}^{-1}, 0.35 \mathrm{~A}$ and $0.45 \mathrm{~A}$, $40 \mathrm{~Pa}$ and $80 \mathrm{~Pa}$, and 0.5 and 1.33 , respectively.

Developing of the design matrix: The $2^{5-1}$ fractional factorial design for this study consisted of 16 factorial runs. The defining relation for this design was $I=$ $A B C D E$ where $A$ represented the oblique angle, $B$ was the rotation speed, $C$ denoted the sputtering DC current, $D$ was the pressure, and $E$ represented the Ar to $\mathrm{N}_{2}$ flow-rate ratio. Every main effect was associated with a four-factor interaction, and every two-factor interaction was aliased with a three-factor interaction. Therefore, the design was resolution $V$. The design provided good information regarding the main effects and two-factor interactions.

Applying the TiN coating as per the design matrix: The oblique-angle coating system consisted of a highvacuum chamber equipped with a 3 " target magnetron gun, $600 \mathrm{~W}$ radio-frequency generator, $400 \mathrm{~W}$ DC-power supply and a turbomolecular pump. The TiN was deposited on the upper hook using DC magnetron sputtering of pure titanium under a mixture of argon (Ar) and nitrogen $\left(\mathrm{N}_{2}\right)$. The TiN deposition experiments were systematically carried out in accordance with the $2^{5-1}$ fractional factorial design. There were five samples for each condition and the experiments were run in a random order to avoid a statistical bias in the analyses. The distance between the substrate (i.e., the upper hooks) and the target (i.e., titanium) was held constant at $5 \mathrm{~cm}$. An oblique-angle sputtering device and an oblique-anglesputtering schematic diagram are illustrated in Figure 2.

Recording the response: The film thickness was measured with a white-light interferometric optical profiler (Polytech model 2000). The deposition rate was calculated from the film thickness and deposition time. The surface microstructure was examined by means of a scanning electron microscope (SEM). SEM measurements (Hitachi model S-4700) were performed in the secondary electron mode at an accelerating voltage of $10 \mathrm{kV}$.

Analyzing the results using the graphical tools for a data analysis and interpretation: Analysis of variance (ANOVA) was used to investigate the effects of the five sputtering-process factors on the average deposition rate. Graphical tools included a normal probability plot of the effects and the main and interaction effect plots of the significant process factors. ${ }^{11,12}$

Determining an appropriate operating condition for the system: The objective of this analysis was to maximize the deposition rate in order to increase the manufacturing throughput of the machine component. The 


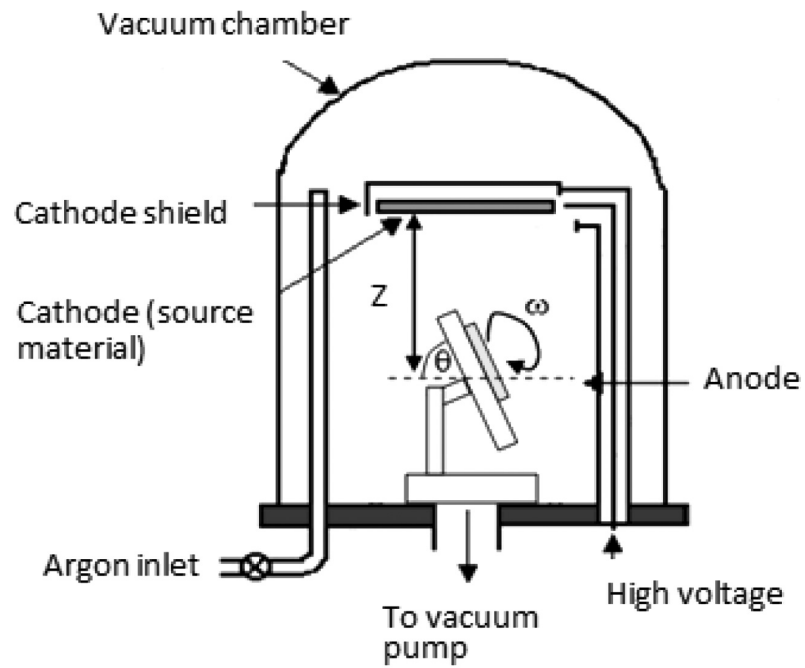

Figure 2: Oblique-angle-sputtering schematic diagram

main and interaction effect plots as well as response surface and contour plots were used to obtain the appropriate statistically significant process factor(s).

\section{RESULTS AND DISCUSSION}

Table 1 shows the matrix design consisting of the five sputtering-process factors together with the corresponding responses (deposition rates). In Table 1, $A, B$, $C, D$ and $E$ represent the factors including the oblique angle, rotational speed, sputtering DC current, pressure, and Ar to $\mathrm{N}_{2}$ flow-rate ratio, respectively.

Table 1: $2^{5-1}$ experimental design for the deposition rate

\begin{tabular}{|c|c|c|c|c|c|}
\hline Factor & \multicolumn{5}{|c|}{ Dep. rate } \\
\hline$A$ & $B$ & $C$ & $D$ & $E$ & \\
\hline 70 & 32 & 0.35 & 40 & 1.33 & 3.8 \\
\hline 80 & 32 & 0.35 & 40 & 0.50 & 1.8 \\
\hline 70 & 64 & 0.35 & 40 & 0.50 & 2.6 \\
\hline 80 & 64 & 0.35 & 40 & 1.33 & 2.4 \\
\hline 70 & 32 & 0.45 & 40 & 0.50 & 4.0 \\
\hline 80 & 32 & 0.45 & 40 & 1.33 & 3.0 \\
\hline 70 & 64 & 0.45 & 40 & 1.33 & 6.2 \\
\hline 80 & 64 & 0.45 & 40 & 0.50 & 2.2 \\
\hline 70 & 32 & 0.35 & 80 & 0.05 & 3.2 \\
\hline 80 & 32 & 0.35 & 80 & 1.33 & 3.5 \\
\hline 70 & 64 & 0.35 & 80 & 1.33 & 5.1 \\
\hline 80 & 64 & 0.35 & 80 & 0.50 & 3.2 \\
\hline 70 & 32 & 0.45 & 80 & 1.33 & 7.3 \\
\hline 80 & 32 & 0.45 & 80 & 0.50 & 3.0 \\
\hline 70 & 64 & 0.45 & 80 & 0.50 & 5.2 \\
\hline 80 & 64 & 0.45 & 80 & 1.33 & 4.2 \\
\hline
\end{tabular}

Figure 3 illustrates the probability plot of the deposition-rate data set. The probability plot shows that the plotted points approximately formed a straight line and fell within the C.I. The AD statistic was small with a high $p$-value compared to the level of significance $(\alpha=$

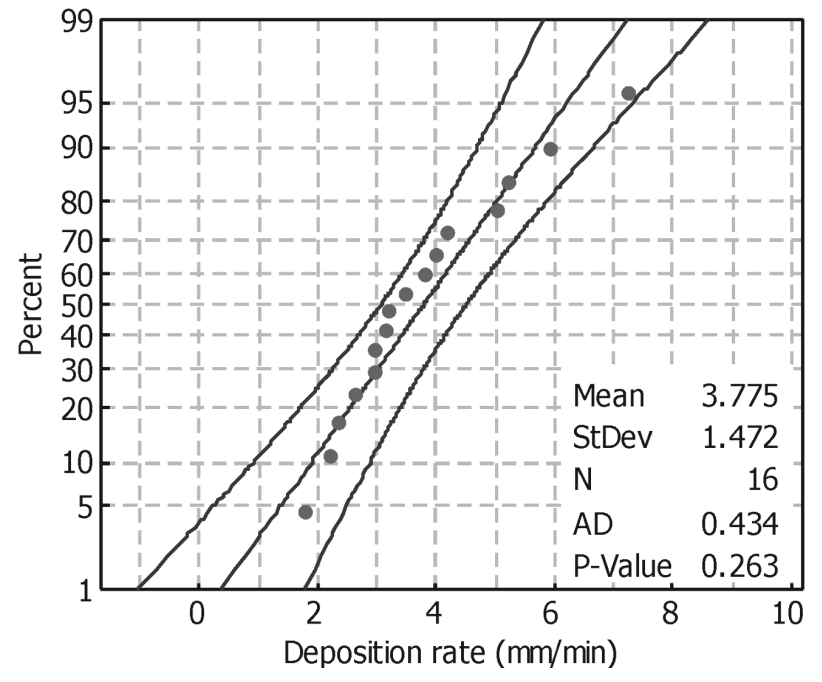

Figure 3: Probability plot of deposition-rate values

$0.05)$. This confirmed that the normal probability distribution fitted the data set of the deposition rate very well.

The adequacy of the underlying model should be checked before performing the statistical analysis and interpretations of the ANOVA. The primary diagnostic tool is a residual analysis. ${ }^{13}$ Figure $4 a$ illustrates the normal probability plot of residuals for the deposition rate of the TiN coating on the upper hooks. Generally, the normal probability plot of residuals does not show anything particularly troublesome, although some residuals bend down slightly on the left side.

If the model is adequate and the assumption is satisfied, the residuals should be structureless. The residuals should be unrelated to any other factors including the predicted response. A plot of residuals versus predicted values is employed to check the non-constant variance. Figure $\mathbf{4 b}$ does not show any violation of the assumption of homogeneity of variances because the plot does not look like an outward-opening funnel or megaphone.

The plot of residuals versus run order or time is used to check the independence assumption. Figure $\mathbf{4 c}$ displays the residuals and the time sequence of data collection for the deposition-rate data. There is no reason to suspect there was a violation of the independence assumption since the plot does not have a pattern such as the sequence of positive and negative residuals.

A normal probability analysis of effects was used to identify the statistically significant main effects and interaction effects on the deposition rate of the TiN coating. The main and interaction effects of the process factors were plotted against the cumulative normal probability (in percent) in this analysis. ${ }^{13}$ Figure 5 illustrates a normal probability plot of effects of the sputtering-process factors on the deposition rate for the $\mathrm{TiN}$ coating. It is worth noting that the effects that fall off from each end of the straight line were deemed to be statistically significant whereas those that fall roughly along the straight line were deemed to be statistically 

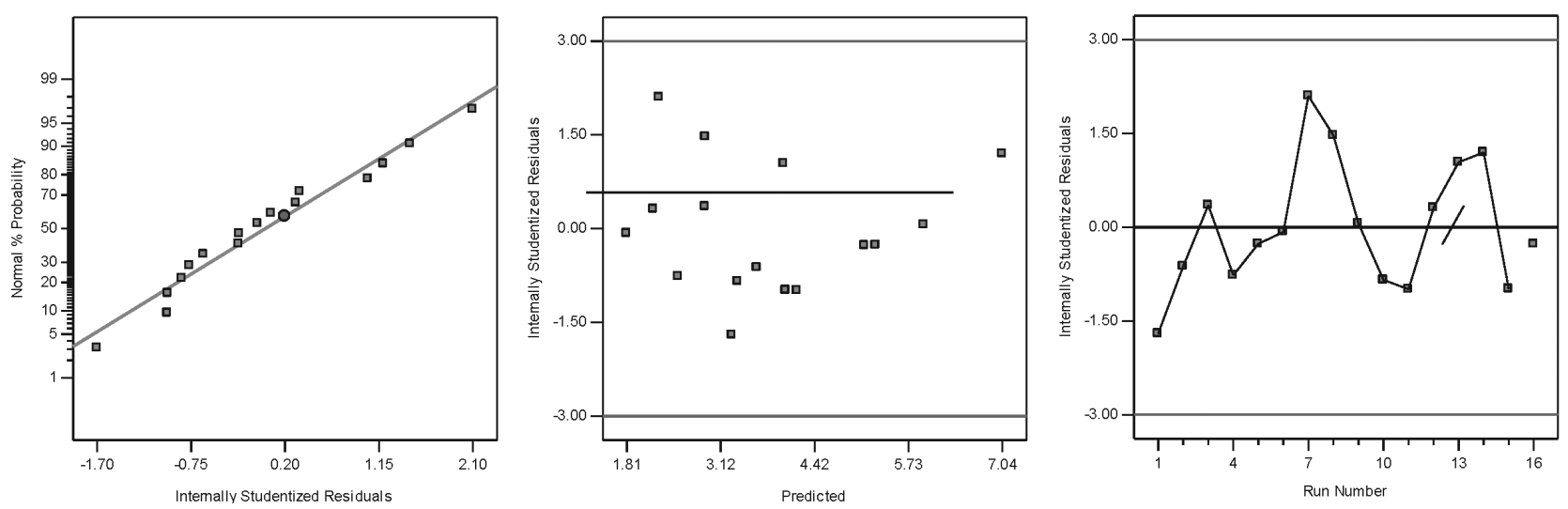

Figure 4: Model adequacy checking of the residuals for deposition-rate values: a) normal probability plot of residuals, b) plot of residuals versus predicted values, c) plot of residuals versus run order

insignificant. The normal-probability data showed that the four process factors, oblique angle (factor $A$ ), DC current (factor $C$ ), pressure (factor $D$ ) and $\operatorname{Ar}$ to $\mathrm{N}_{2}$ flow-rate ratio (factor $E$ ) had significant impacts on the average deposition rate. Furthermore, interaction effects between oblique angle and DC current $(A \times C)$ and oblique angle and Ar to $\mathrm{N}_{2}$ flow-rate ratio $(A \times E)$ were statistically significant at a significance level of 0.05 .

The result from Table 1 was analyzed with ANOVA, which was employed for investigating the effects of the five sputtering-process factors on the average deposition rate of the TiN coating. Table 2 shows that the model $F$-value of 87.85 with a very small $p$-value was adequate, having a large coefficient of determination $\left(R^{2}\right)$ of 0.9832 ; it was defined as the ratio of the explained variation to the total variation and was a measure of the degree of fit. The adjusted $R^{2}$ of 0.9720 and predicted $R^{2}$ of 0.9469 were in reasonable agreement where the difference between the two values was less than 0.2. Table 2 also shows that the sources of variation with a $p$-value of less than 0.05 were considered to have a statistically significant contribution to the average deposition rate. The ANOVA results for a reduced model obtained by selecting the statistically significant terms

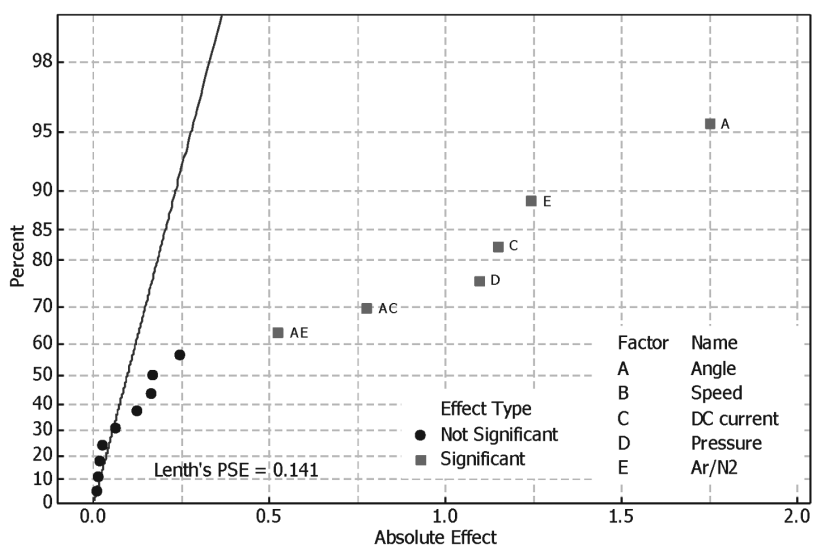

Figure 5: Normal probability plot of effects for the deposition rate of TiN coating with the 0.05 level of significance indicated that the most statistically significant factor affecting the average deposition rate was the oblique angle, which explained the largest contribution, accounting for $37.64 \%$ of the total variability. The Ar to $\mathrm{N}_{2}$ flow-rate ratio, DC current and pressure had lower contribution levels; similarly, the interaction of oblique angle and DC current, and the interaction of oblique angle and Ar to $\mathrm{N}_{2}$ flow-rate ratio also had lower contribution levels.

In order to interpret the interaction effect effectively, interaction plots were constructed as shown in Figure 6. Here, non-parallel lines reveal that there were interactions between the oblique angle and DC current as well as between the oblique angle and $\mathrm{Ar}$ to $\mathrm{N}_{2}$ flow-rate ratio. The effect of the oblique angle on the deposition rate was different at low and high levels of DC current. This showed that the maximum deposition rate was obtained when the oblique angle was at a low level $\left(75^{\circ}\right)$ and the DC current was at a high level (0.45 A). Similarly, the interaction effect plot also clearly indicated that the maximum deposition rate was found when the oblique angle was at a low level $\left(75^{\circ}\right)$ and the $\mathrm{Ar}$ to $\mathrm{N}_{2}$ flow-rate ratio was at a high level (1.33).

To determine the appropriate operating conditions of the significant process factors affecting the deposition

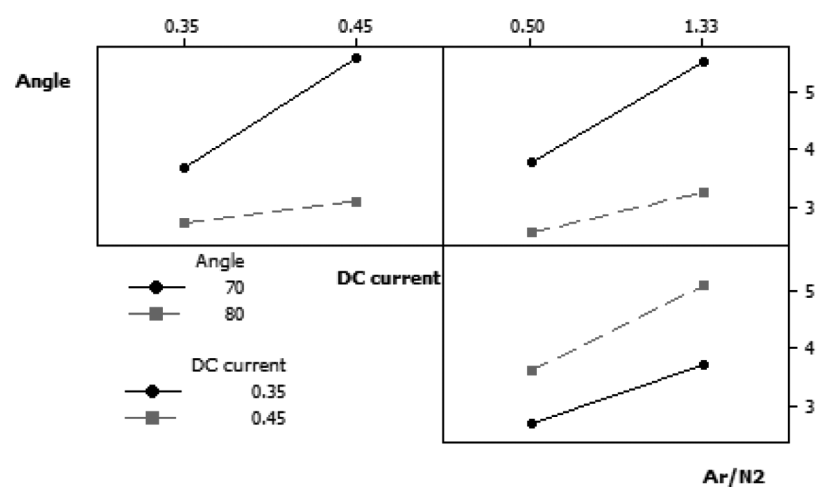

Figure 6: Interaction plots of angle, DC current and $\mathrm{Ar} / \mathrm{N}_{2}$ for the deposition rate of TiN coating 


\section{SAIKAEW: PROCESS FACTORS AFFECTING DEPOSITION RATE OF TiN COATING ON A MACHINE COMPONENT}

Table 2: ANOVA table for the deposition rate of TiN coating

\begin{tabular}{|c|c|c|c|c|c|c|}
\hline Source of variation & Sum of squares & $\begin{array}{c}\text { Degree of } \\
\text { freedom }\end{array}$ & Mean square & $F$-value & $p$-value & $\%$ contribution \\
\hline Model & 31.96 & 6 & 5.33 & 87.85 & $<0.0001$ & \\
\hline$A$-Angle & 12.24 & 1 & 12.24 & 210.82 & $<0.0001$ & 37.64 \\
\hline$C$-DC current & 5.26 & 1 & 5.26 & 86.84 & $<0.0001$ & 16.20 \\
\hline$D$-Pressure & 4.79 & 1 & 4.79 & 79.07 & $<0.0001$ & 14.75 \\
\hline$E$-Ar/ $\mathrm{N}_{2}$ & 6.17 & 1 & 6.17 & 101.73 & $<0.0001$ & 18.98 \\
\hline$A C$ & 2.40 & 1 & 2.40 & 39.60 & 0.0001 & 7.39 \\
\hline$A E$ & 1.10 & 1 & 1.10 & 18.06 & 0.0021 & 3.37 \\
\hline Residual & 0.55 & 9 & 0.061 & & & \\
\hline Total & 32.50 & 15 & & & & \\
\hline
\end{tabular}

rate for the TiN coating of the fishing-net weavingmachine component, a numerical analysis using the response surface methodology was carried out. After performing the regression analysis, the empirical relationship between the deposition rate and the oblique angle, pressure, DC current and Ar to $\mathrm{N}_{2}$ flow-rate ratio was:

$R=3.77-0.87 A+0.57 C+0.55 D+0.62 E-0.39 A C-$ $0.26 A E$

Response-surface plots and contour plots for the deposition-rate response in terms of oblique angle and DC current and oblique angle and $\mathrm{Ar}$ to $\mathrm{N}_{2}$ flow-rate ratio were constructed using Equation (1) as shown in Figure 7. We can notice that the deposition rate was higher in the region of a low oblique angle, high DC current and high Ar to $\mathrm{N}_{2}$ flow-rate ratio. The positive signs for the coefficients of pressure, DC current and Ar to $\mathrm{N}_{2}$ flow-rate ratio in the fitted model for the deposition rate indicated that the deposition rate increased with
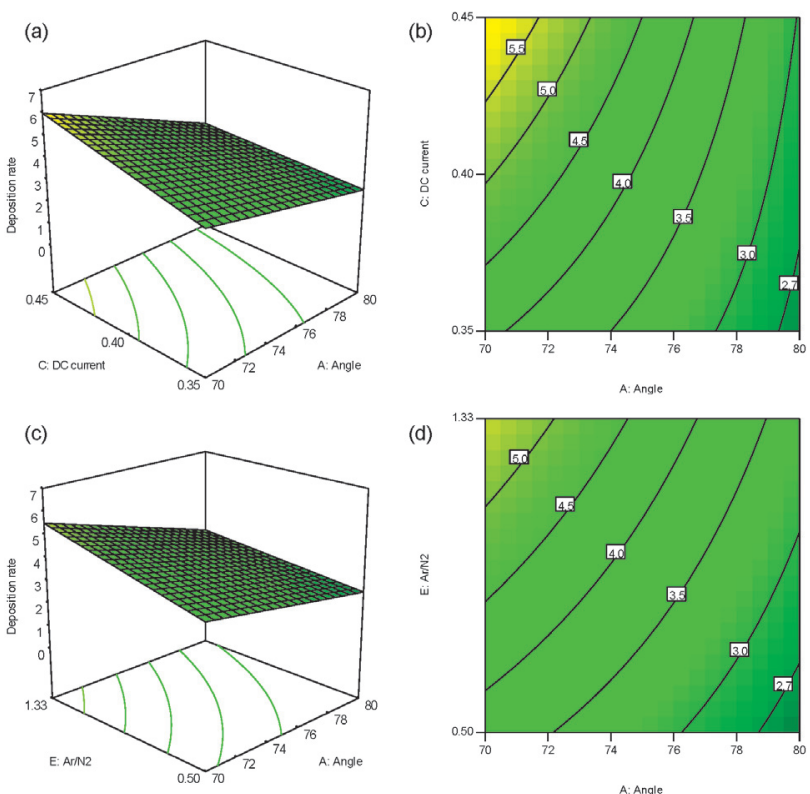

Figure 7: a) Response surface plot, b) contour plot for oblique angle and DC current, c) response surface plot, d) contour plot for oblique angle and $\mathrm{Ar}$ to $\mathrm{N}_{2}$ flow-rate ratio increasing levels of the process factors. On the other hand, the negative sign of the oblique angle showed that the deposition rate increased with a decreasing level of this factor. Furthermore, the negative signs for the coefficients of the two interactions meant that an increase in the deposition rate was obtained due to simultaneous changes of the process factors in the opposite directions. The contour plots and response-surface plots also confirmed that the maximum deposition rate was found when the oblique angle was at a low level $\left(75^{\circ}\right)$, DC current at a high level $(0.45 \mathrm{~A})$ and $\mathrm{Ar}$ to $\mathrm{N}_{2}$ flow-rate ratio also at a high level (1.33). Jing et al. stated that the deposition rate of TiN deposited on a 316L stainless-steel substrate increased with a decreasing inclination angle, which could be treated as a geometrical issue. ${ }^{14}$

Figure 8 shows the plot of experimental observations and predicted values, used to investigate whether the statistical model fits the experimental observations. ${ }^{13}$ The plot illustrates that most of the data points lie in a straight line. This indicates that the statistical model fits the experimental observations for the TiN coating on the machine component.

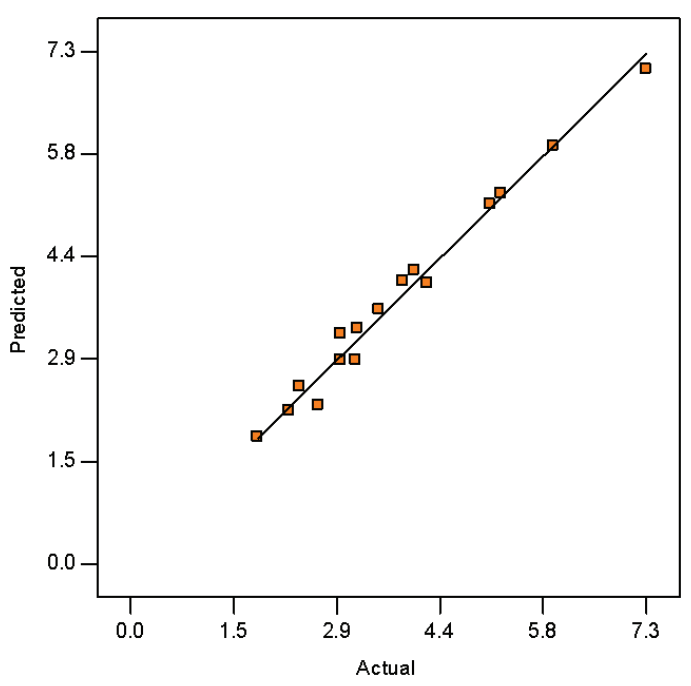

Figure 8: Relationship between the actual deposition rate and predicted deposition rate 

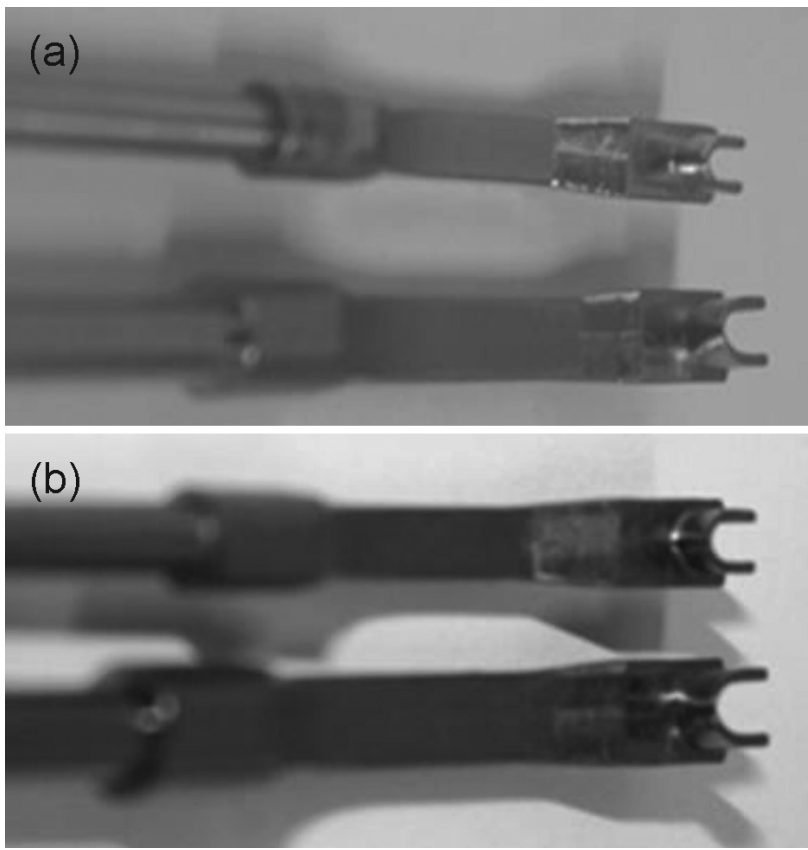

Figure 9: Photographs of the upper hooks: a) before, b) after the TiN coating

Figures 9a and $\mathbf{b}$ show photographs of the upper hooks before and after the TiN coating, respectively. Before the coating, the upper hooks were silver, with the small one being shinier. This was because the small one was pre-coated with chromium. After the coating, the upper hooks were of a dark yellowish color, indicating a successful TiN coating.

Figure 10 shows typical SEM micrographs of the upper hooks before and after the TiN coating. First, the hook surface was very rough indicating many microscratches and pits. After the coating, the hook surface became smooth. Large pits and scratches were diminished whereas most of the fine scratches and pits disappeared. Thus, the surface roughness of the upperhook surface could be significantly decreased by coating it with sputtered TiN. The coating was expected to provide a considerable improvement in the surface quality regarding the wear resistance of the upper hook.

\section{CONCLUSIONS}

This work investigated the effect of sputtering process factors on the average deposition rate in order to enhance the manufacturing-process quality of a TiN coating on a machine component of a fishing-net weaving machine. A $2^{5-1}$ fractional factorial design, ANOVA and other statistical-analysis tools were used to find the statistically significant process factors and to obtain the appropriate operating conditions for the significant factors. The results of this study can be summarized as follows:

The oblique angle made the largest contribution to the total variability at a 0.05 significance level.
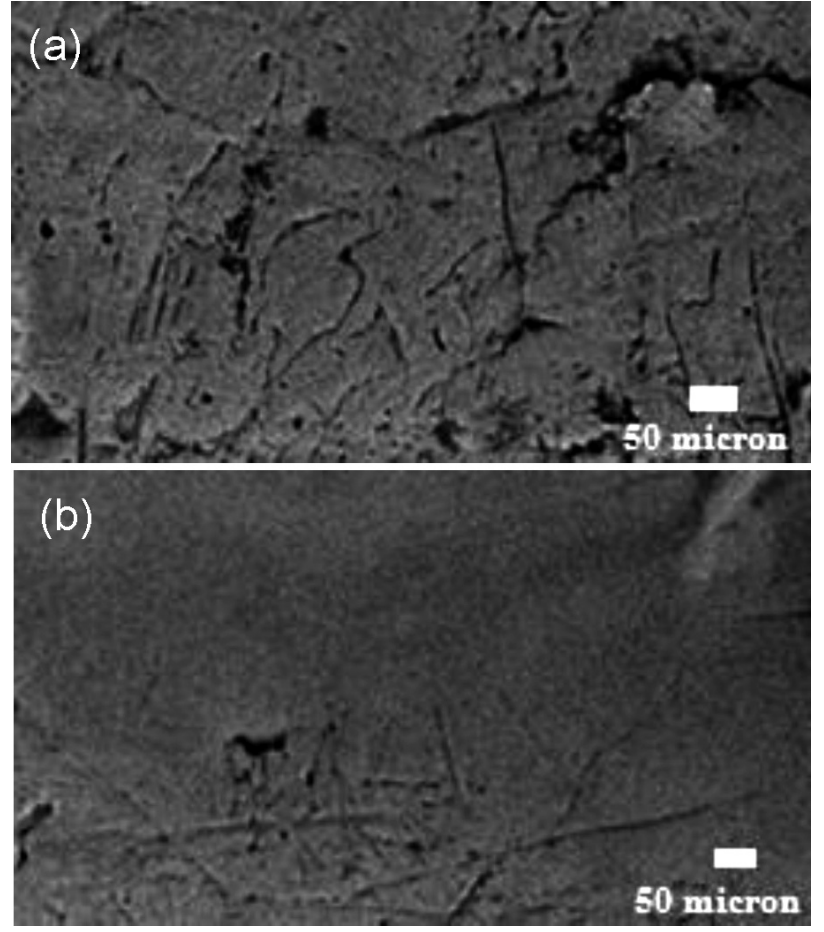

Figure 10: Typical SEM micrographs of the upper hooks: a) before and $b$ ) after the TiN coating

The Ar to $\mathrm{N}_{2}$ flow-rate ratio, DC current and pressure had lower contribution levels.

The interaction of the oblique angle and DC current and the interaction of the oblique angle and $\mathrm{Ar}$ to $\mathrm{N}_{2}$ flow-rate ratio had lower contribution levels.

The highest deposition rate was found when the oblique angle was $75^{\circ}$, DC current was $0.45 \mathrm{~A}$ and Ar to $\mathrm{N}_{2}$ flow-rate ratio was 1.33 .

Further research should investigate the performance of TiN by carrying out wear experiments on the machine components of a real fishing-net weaving machine. Moreover, appropriate operating conditions for the process factors should be determined using the response surface methodology coupled with the desirability function approach, based on the data sets for the deposition rate and wear rate. ${ }^{15,16}$

\section{Acknowledgement}

The author gratefully acknowledges the Thailand Research Fund (TRF), grant no. RSA 5980025, and the Faculty of Engineering, Khon Kaen University for the financial supports of this research.

\section{REFERENCES}

${ }^{1}$ Y. Küçük, A. Öztel, M. Y. Balalý, M. Öge, M. S. Gök, Evaluation of the wear behavior of nitride-based PVD coatings using different multi-criteria decision-making methods, Mater. Tehnol., 51 (2017), 307-316, doi:10.17222/mit.2016.041

${ }^{2}$ D. S. Stone, K. B. Yoder, W. D. Sproul, Hardness and elastic modulus of TiN based on continuous indentation technique and new 


\section{SAIKAEW: PROCESS FACTORS AFFECTING DEPOSITION RATE OF TiN COATING ON A MACHINE COMPONENT}

correlation, J. Vac. Sci. Technol. A, 9 (1991) 4, 2543-2547, doi:10.1002/adfm.201002062

${ }^{3}$ G. S. Kim, S. Y. Lee, J. H. Hahn, B. Y. Lee, J. G. Han, J. H. Lee Effects of the thickness of $\mathrm{Ti}$ buffer layer on the mechanical properties of TiN coatings, Surf. Coat. Technol., 171 (2003), 83-90 doi:10.1016/S0257-8972(03)00243-3

${ }^{4}$ V. H. Pham, S. W. Yook, E. J. Lee, Y. Li, G. Jeon, J. J. Lee, H. E. Kim, Y. H. Koh, Deposition of TiN films on Co-Cr for improving mechanical properties and biocompatibility using reactive DC sputtering, J. Mater. Sci., 22 (2011), 2231-2237, doi:10.1007/ s10856-011-4410-8

${ }^{5}$ Z. Xie, X. Liu, W. Wang, C. Liu, Z. Li, Z. Zhang, Fabrication of TiN nanostructure as a hydrogen peroxide sensor by oblique angle deposition, Nanoscale Res. Lett., 9 (2014), 105, doi:10.1186/1556276X-9-105

${ }^{6}$ B. Bouaouina, C. Mastail, A. Besnard, R. Mareus, F. Nita, A Michel, G. Abadias, Nanocolumnar TiN thin film growth by oblique angle sputter-deposition: Experiments vs. simulations, Mater. Des. 160 (2018), 338-349, doi:10.1016/j.matdes.2018.09.023

${ }^{7}$ M. A. Domínguez-Crespo, A. M. Torres-Huerta, E. Rodríguez, A. Gonzalez-Hernandez, S. B. Brachetti-Sibaja, H. J. Dorantes-Rosales, A. B. Lopez-Oyama, Effect of deposition parameters on structural, mechanical and electrochemical properties in $\mathrm{Ti} / \mathrm{TiN}$ thin films on AISI 316L substrates produced by r. f. magnetron sputtering, J. Alloy Compd., 746 (2018), 688-698, doi:10.1016/j.jallcom.2018.02.319

${ }^{8}$ P. Pedrosa, D. Machado, P. Fiedler, B. Vasconcelos, E. Alves, N. P. Barradas, N. Martin, J. Haueisen, F. Vaz, C. Fonseca, Electrochemical characterization of nanostructured $\mathrm{Ag}$ :TiN thin films produced by glancing angle deposition on polyurethane substrates for bio-electrode applications, J. Electroanal. Chem., 768 (2016), 110-120, doi:10.1016/j.jelechem.2016.03.005

${ }^{9}$ P. Pedrosa, C. Lopes, N. Martin, C. Fonseca, F. Vaz, Electrical characterization of $\mathrm{Ag}$ : TiN thin films produced by glancing angle deposition, Mater. Lett., 115 (2014), 136-139, doi:10.1016/j.matlet. 2013.10.044

${ }^{10}$ J. Lintymer, N. Martin, J. M. Chappe, J. Takadoum, Glancing angle deposition to control microstructure and roughness of chromium thin films, Wear, 264 (2008), 444-449, doi:10.1016/j.wear.2006.08.036

${ }^{11}$ StatEase Inc., Design Expert 7 (software), User's Guide, Minneapolis 2005

${ }^{12}$ Minitab Inc., Minitab 13 (software), State College, U.S.A., 2013

${ }^{13}$ D. C. Montgomer, Design and Analysis of Experiments, $6^{\text {th }}$ ed., John Wiley \& Sons, New York 2005

${ }^{14}$ F. Jiang, T. F. Zhang, B. H. Wu, Y. Yu, Y. P. Wu, Sh. F. Zhu, F. J. Jing, N. Huang, Y. X. Leng, Structure mechanical and corrosion properties of TiN films deposited on stainless steel substrates with different inclination angles by DCMS and HPPMS, Surf. Coat. Technol., 292 (2016), 54-62, doi:10.1016/j.surfcoat.2016.03.007

${ }^{15}$ G. Derringer, R. Suich, Simultaneous optimization of several response variables, J. Qual. Technol., 12 (1980) 4, 214-219, doi:10.1080/00224065.1980.11980968

${ }^{16}$ R. H. Myer, D. C. Montgomer, Response Surface Methodology: Process and Product Optimization Using Designed Experiments, $2^{\text {nd }}$ ed., John Wiley \& Sons, New York 2002 